Ivete de Aquino Freire, Ramón Núñes Cárdenas, Manifestação de Lazer na História de Vida de Idosas... Rosa de Luz A. Dos Reis Miranda Sá,

Ednes P. Dos Santos Souza e Paola Lima Tristão

\title{
MANIFESTAÇÃO DE LAZER NA HISTÓRIA DE VIDA DE IDOSAS DO GRUPO PIONEIRAS DE RONDÔNIA PRÁTICAS DE LAZER NA FASE ADULTA ${ }^{1}$
}

Recebido em: 18/11/2017

Aceito em: 20/04/2018

Ivete de Aquino Freire ${ }^{2}$ Ramón Núñes Cárdenas ${ }^{3}$

Universidade Federal de Rondônia Porto Velho - RO - Brasil

Rosa de Luz Ambrósio dos Reis Miranda Sá ${ }^{4}$ Serviço Social do Comercial - Seccional Rondônia Porto Velho - RO - Brasil

Ednes Pereira dos Santos Souza ${ }^{5}$

Faculdade Metropolitana de Porto Velho Porto Velho - RO - Brasil

Paola Lima Tristão ${ }^{6}$

Universidade Federal de Rondônia - UNIR

Porto Velho - RO - Brasil

RESUMO: O objetivo da pesquisa foi identificar e caracterizar as práticas de lazer durante a maturidade de idosas. Utilizou-se à abordagem qualitativa, com opção metodológica pela História de Vida. A população participante da pesquisa foi de 9 (nove) idosas com idade acima de 80 (oitenta) anos, participantes do grupo de convivência "Pioneiras de Rondônia". Realizaram-se entrevistas do tipo aberta; e para

\footnotetext{
${ }^{1}$ Artigo premiado no $29^{\circ}$ Encontro Nacional de Recreação e Lazer (ENAREL), realizado em Caruaru/PE em 2017.

2 Doutora Sociedad y Culturas Contemporáneas. Docente do departamento de Educação física da Universidade Federal de Rondônia. Grupo de Estudo e Desenvolvimento da Cultura Corporal - UNIR. Centro de Desenvolvimento de Pesquisa em Políticas de Esporte e de Lazer da Rede Cedes do Estado de Rondônia.

3 Graduado em Licenciatura em Educação Física. Doutor em Biologia Experimental. Docente do Departamento de Educação Física da Universidade Federal de Rondônia. Grupo de Estudo e Desenvolvimento da Cultura Corporal - UNIR. Centro de Desenvolvimento de Pesquisa em Políticas de Esporte e de Lazer da Rede Cedes do Estado de Rondônia.

${ }^{4}$ Graduada em Educação Física - Universidade Federal de Rondônia. Especialista em Ciência do Movimento Humano Sub-área Educação Física Escolar. Grupo de Estudo e Desenvolvimento da Cultura Corporal- UNIR

${ }^{5}$ Graduada em Educação Física - Instituto Luterano de Ensino Superior. Especialista em Ciência do Movimento Humano. Grupo de Estudo e Desenvolvimento da Cultura Corporal - UNIR

${ }^{6}$ Graduanda Licenciatura em Educação Física. Grupo de Estudo e Desenvolvimento da Cultura Corporal - UNIR. Universidade Federal de Rondônia - UNIR
} 
Ivete de Aquino Freire, Ramón Núñes Cárdenas, Manifestação de Lazer na História de Vida de Idosas... Rosa de Luz A. Dos Reis Miranda Sá,

Ednes P. Dos Santos Souza e Paola Lima Tristão

registro, o recurso de gravação. Para identificar as depoentes, lhes foram atribuídos nomes indígenas. As práticas de lazer das idosas durante a maturidade eram bastante limitadas. Esta restrição, por um lado, se devia a precariedade na infraestrutura destinada ao lazer na cidade de Porto Velho que oferecia escassez em quantidade e qualidade. $\mathrm{O}$ baixo poder aquisitivo e a dedicação de grande parte do tempo ao trabalho dentro e fora do lar, eram fatores que também limitavam o lazer.

PALAVRAS CHAVE: Atividades de Lazer. Idoso. Mulheres.

\section{MANIFESTATION OF LEISURE IN THE LIFE HISTORY OF ELDERS IN THE RONDÔNIA PIONEERS GROUP: LEISURE PRACTICES IN THE ADULT PHASE}

ABSTRACT : The objective of the research was to identify and characterize leisure practices during the adult phase of the elderly. We used the qualitative approach, with methodological option for the History of Life. The population that participated in the research was 9 (nine) elderly women over 80 years of age, participants in the "Pioneiras de Rondônia" cohabitation group. Open type interviews were conducted; and for recording, the recording feature. To identify the deponents, they were given indigenous names. The leisure practices of the elderly during maturity were very limited. This restriction, on the one hand, was due to the precariousness of the leisure infrastructure in the city of Porto Velho, which offered scarcity in quantity and quality. The low purchasing power and dedication of much of the time to work inside and outside the home were factors that also limited leisure.

KEYWORDS: Leisure Activities. Aged. Women.

\section{Introdução}

A idade adulta é um estágio da vida que igualmente aos demais ciclos, apresentam suas características próprias. Além daquelas relacionadas ao desenvolvimento humano com enfoque biológico e psicológico, também ressaltam os aspectos produtivos e as relações interpessoais de um modo diferente daquele da criança, e do jovem (OLIVEIRA, 1999).

Mosquera (1987) nos auxilia a compreender esta etapa da vida partir da perspectiva cronológica classificando-a em: idade adulta jovem, média e velha. Dentro dessas três divisões e concepções de vida adulta, apresentam-se outras subcategorias: a idade adulta jovem subdivide-se em fase inicial denominada idade adulta jovem inicial, 
Ivete de Aquino Freire, Ramón Núñes Cárdenas, Manifestação de Lazer na História de Vida de Idosas... Rosa de Luz A. Dos Reis Miranda Sá,

Ednes P. Dos Santos Souza e Paola Lima Tristão

com idade aproximada entre 20 e 25 anos. Em seguida, a idade adulta jovem plena, que compreende dos 25 a 35 anos, e, por fim, a idade adulta jovem final, abrangendo dos 35 aos 40 anos de idade. Para classificação anterior levam-se em consideração as características físicas da pessoa; sua vitalidade, energia, disposição psicológica, a valorização da individualidade, forte impulsos, alegria de viver, busca da valorização pessoal, recompensas rápidas e externas, motivações para demonstração de competência, entre outros.

Do ponto de vista legal, o Código Civil Brasileiro, de 2003, alterou a idade de referência para a maioridade, determinando que a menoridade cesse aos 18 anos completos, quando a pessoa fica habilitada à prática de todos os atos da vida civil. $\mathrm{O}$ Código Penal de 1940, com as modificações na parte geral trazidas em 1984, ainda em vigor, estabelece que a responsabilidade penal inicia-se aos 18 anos. O mesmo marco foi consagrado na Constituição Federal de 1988.

Dentre os fatores mencionados anteriormente, para a compreensão da maturidade, também se destacam as variáveis socioculturais. Decorrente desta multiplicidade de dimensões é comum encontrarmos afirmações como a de Alves e Marcellino (2010) a qual concordamos: não é fácil identificar em que momento uma pessoa se torna adulta. Apesar das dificuldades, os autores mencionados anteriormente optam por considerar adulto,

O grupo de pessoas que assume novas responsabilidades e conseguem, em alguns momentos, identificar sentido e significação em suas ações e essencialmente tem obrigações a cumprir. Em sua grande maioria, os adultos são responsáveis pelo sustento próprio e/ou da família e são vistos pela sociedade como pessoas produtivas no tempo de trabalho. São, ainda, os mantenedores da relação de produção e consumo do sistema econômico instaurado em nossa sociedade (p. 104). 
Ivete de Aquino Freire, Ramón Núñes Cárdenas, Manifestação de Lazer na História de Vida de Idosas... Rosa de Luz A. Dos Reis Miranda Sá,

Ednes P. Dos Santos Souza e Paola Lima Tristão

Frente às responsabilidades assumidas, sobretudo aquelas relacionadas com o sustento da família, citam ainda os autores que a maturidade representa uma fase de crescente obrigação e produtividade.

Oliveira (1999) destaca que ao abordar aspectos relativos à idade adulta é importante que sejam contextualizados na discussão, de que adultos se está fazendo referência. Parece ser que o autor guarda restrições sobre uma análise generalizada do adulto. É certo, pois, em um sistema capitalista, por exemplo, no qual a maioria da população vivencia o trabalho como principal ocupação, é diferente de outros sistemas sociais que valorizam as distintas dimensões de expressão humana. Igualmente, dentro de um mesmo sistema capitalista, se distinguem as condições de trabalho e de vida de populações mais abastadas daquelas de estratos socioeconômicos mais baixos. Neste contexto, mais do que considerar uma caracterização geral, é importante inserir em uma análise toda a trajetória de vida deste adulto, apreciando, inclusive, sua origem sociocultural.

No presente estudo, os sujeitos adultos que vamos fazer referência são mulheres, que nasceram na região Amazônica brasileira, residentes na cidade de Porto Velho, no estado de Rondônia. Assumiram a responsabilidade que a maturidade lhe impunha através do casamento e construção de uma família. Em sua maioria exerceram na infância e na adolescência trabalhos domésticos, dentro e ou fora do lar. Este último, frequentemente não remunerado.

Estas mulheres viviam em um contexto específico, na Amazônia, mais precisamente em uma localidade (Porto Velho), que à época sofreu três mudanças na sua identificação geográfica. Conforme Gorayeb (2015), até 1940, a localidade era município do Estado do Amazonas; a partir desta data é instituído como um município 
Ivete de Aquino Freire, Ramón Núñes Cárdenas, Manifestação de Lazer na História de Vida de Idosas... Rosa de Luz A. Dos Reis Miranda Sá,

Ednes P. Dos Santos Souza e Paola Lima Tristão

do Território Federal do Guaporé; e em 1956 se torna município do Território Federal de Rondônia. Atualmente é capital do estado de Rondônia.

O contexto socioeconômico da época em que as mulheres pesquisadas se encontravam na maturidade, era alentador uma vez que acenava para uma fase de transição positiva, vislumbrada no governo de Vargas: de uma cidade com péssimas perspectivas de desenvolvimento para ser uma localidade inserida nas políticas elaboradas para todo o Brasil, especialmente para a região do Guaporé.

De acordo com Gomes (2013) a localidade sofria com o desastre econômico decorrente da crise internacional da comercialização da borracha, mas contava com um Governo Federal patriótico, defensor dos seus filhos e filhas, o que melhorava os ânimos e apontava novos caminhos. Em 1930 a situação se tornou crítica, levando o Governo Federal a intervir na administração da localidade (GORAYEB, 2015). A partir deste episódio, criaram-se expectativas de desenvolvimento para a região.

Considerando o exposto, buscou-se estudar as manifestações de lazer de idosas amazônicas, residentes em Porto Velho durante o período em que estas se encontravam na maturidade ou na denominada fase adulta. Afim de melhor orientar a pesquisa, determinaram-se os seguintes objetivos específicos: a) identificar e caracterizar as práticas de lazer das idosas quando se encontravam na maturidade; b) estabelecer relação entre as práticas de lazer e o contexto social, econômico e cultural das mulheres; c) relatar os espaços de lazer utilizados; d) descrever os materiais e equipamentos utilizados nas práticas de lazer; e) identificar os distintos grupos de compartilhamento de práticas de lazer das mulheres.

Dentre os conceitos de lazer, é comum a identificação do termo "tempo livre". Esta expressão adquire importância no contexto deste trabalho na medida em que as 
Ivete de Aquino Freire, Ramón Núñes Cárdenas, Manifestação de Lazer na História de Vida de Idosas... Rosa de Luz A. Dos Reis Miranda Sá,

Ednes P. Dos Santos Souza e Paola Lima Tristão

manifestações de lazer estudadas ocorriam em um período em que se iniciavam as discussões teóricas nos grandes centros de pesquisa do mundo sobre o tema e as políticas públicas brasileiras neste setor eram inexistentes na região amazônica e incipientes na maioria das localidades brasileiras. Somado a esta questão, recorremos a Moura e Souza (2013) quando destacam que no decorrer da vida se percebe que a quantidade de tempo livre é maior na infância e adolescência, diminuindo na fase adulta e aumentando com a aposentadoria. Isto porque, conforme já comentado anteriormente, é na fase adulta que o indivíduo assume novas responsabilidades, ocupações e compromissos sociais.

\section{Materiais e Métodos}

A pesquisa "Manifestação de lazer na história de vida das idosas que participam do grupo as Pioneiras de Rondônia: identificação e características das práticas de lazer na fase adulta" é subprojeto de um projeto mais amplo denominado "Políticas Públicas de Esporte e Lazer do Estado de Rondônia: Diagnóstico das necessidades e potencialidades" desenvolvida pelo Centro de Desenvolvimento de Pesquisa em Políticas de Esporte e de Lazer da Rede Cedes do Estado de Rondônia.

Participaram do estudo 09 (nove) mulheres com idade igual ou superior a 80 anos, integrantes do grupo de convivência Pioneiras de Rondônia. Todas são mulheres que nasceram na Região Amazônica ou que vieram para esta localidade ainda na infância. Estimou-se que a maturidade das mesmas ocorreu no período aproximado entre 1949 e 1968.

Para alcançar o objetivo proposto na pesquisa, foram realizadas entrevistas do tipo aberta contendo as seguintes categorias de análise, que geraram, por sua, vez, 
Ivete de Aquino Freire, Ramón Núñes Cárdenas, Manifestação de Lazer na História de Vida de Idosas... Rosa de Luz A. Dos Reis Miranda Sá,

Ednes P. Dos Santos Souza e Paola Lima Tristão

subcategorias: a) local e data de nascimento; b) aspectos familiares; c) características do Lazer; d) mundo profissional; e) infraestrutura de moradia.

Do ponto de vista metodológico, o trabalho seguiu a orientação de Sais apud Ploner et al. (2017) quando afirma que as pessoas têm as suas singularidades inscritas em um período histórico com desejos e significações próprias.

O estudo foi realizado numa abordagem qualitativa, com opção metodológica pela História de Vida. Segundo Spindola e Santos (2003), a História de Vida é uma das modalidades de estudo que trabalha com a estória, o relato de vida, ou seja, a história contada por quem a vivenciou. No relato, o que interessa ao pesquisador é o ponto de vista do sujeito. Nas palavras de Glat citado por Spindola e Santos (2003), o objetivo desse tipo de estudo é apreender e compreender a vida conforme ela é relatada e interpretada pelo próprio ator $\mathrm{O}$ método de História de Vida ressalta o momento histórico vivido pelo sujeito. Assim esse método é necessariamente histórico (a temporalidade contida no relato individual remete ao tempo histórico), dinâmico (apreende as estruturas de relações sociais e os processos de mudanças) e dialético (teoria e prática são constantemente colocados em confronto durante a investigação) (BRIOSCHI apud SPINDOLA e SANTOS, 2003).

Para a realização da pesquisa obteve-se o consentimento dos sujeitos a partir da assinatura do TCLE bem como a aprovação pelo Comitê de Ética em Pesquisa da Universidade Federal de Rondônia.

A fim de garantir o anonimato das mulheres participantes do estudo e ao mesmo tempo identificá-las no contexto da pesquisa, lhes foram atribuídos nomes indígenas como Yara, Aracy, Iracema, Janaína, Thainá, Thaynara, Jurema, Anahí e Apuãna. A Figura 1 apresenta uma síntese da história de vida das depoentes. 
Ivete de Aquino Freire, Ramón Núñes Cárdenas, Manifestação de Lazer na História de Vida de Idosas...

Rosa de Luz A. Dos Reis Miranda Sá,

Ednes P. Dos Santos Souza e Paola Lima Tristão

Figura 1: Breve histórico de vida das depoentes

\begin{tabular}{|c|c|}
\hline $\begin{array}{l}\text { Identificaçã } \\
\text { o }\end{array}$ & Breve história de vida das depoentes \\
\hline Iracema & $\begin{array}{l}\text { Com } 5 \text { anos foi dada pelos pais em adoção a uma família Turca. Desde então não teve mais } \\
\text { contato com a família consanguínea. Estudou durante } 2 \text { anos em ensino informal com uma } \\
\text { professora que a atendia em sua residência. }\end{array}$ \\
\hline Yara & $\begin{array}{l}\text { Não conheceu os pais e nem avós. Na infância morou com uma tia. Na adolescência, por } \\
\text { decisão judicial morou inicialmente com uma família e pouco tempo depois foi destinada para } \\
\text { outra. Era responsável pelos trabalhos domésticos e cuidava das duas crianças do casal. } \\
\text { Frequentou as primeiras séries escolares quando morava com a primeira família a qual foi } \\
\text { destinada. }\end{array}$ \\
\hline Jurema & $\begin{array}{l}\text { Não conheceu seus pais e nem avós. Na primeira infância morou com uma irmã e mais tarde } \\
\text { com uma família de desconhecidos. Ainda criança era responsável pelos trabalhos domésticos } \\
\text { em troca de casa, comida e roupa. Nunca frequentou a escola. }\end{array}$ \\
\hline Tainá & $\begin{array}{l}\text { Sempre morou com os pais e frequentou a escola com regularidade. Teve acesso ao lazer, } \\
\text { cuidados e afeto por parte dos pais. Após a conclusão do ensino ginasial cursou a formação } \\
\text { pedagógica intensiva para atuar como professora. }\end{array}$ \\
\hline Apuana & $\begin{array}{l}\text { Filha de mãe solteira, a partir dos } 7 \text { anos passou pela casa de várias família para trabalhar. } \\
\text { Antes disso já ajudava a mãe no roçado. Junto as família que a recebia, Apuana era } \\
\text { responsável pelos trabalhos domésticos em troca de casa, comida e roupa. Permaneceu com } \\
\text { esta rotina de vida até casar-se. Começou a frequentar a escola com } 50 \text { anos de idade. }\end{array}$ \\
\hline Aracy & $\begin{array}{l}\text { Órfão de pai, foi criada com a mãe e o padrasto. Teve } 4 \text { irmãos do primeiro casamento da mãe } \\
\text { e } 8 \text { de segundo matrimônio. Dos } 13 \text { filhos somente } 7 \text { chegaram a fase adulta. Desde criança já } \\
\text { ajudava no trabalho da família que consistia em costurar chapéu de palha de Carnaúba. Tinha } \\
\text { um tempo aos domingos para brincar. Estudou até a } 4^{\text {a }} \text { série primária em uma escola informal } \\
\text { na paróquia da igreja, nesta época tinha } 15 \text { anos. }\end{array}$ \\
\hline Anahi & $\begin{array}{l}\text { Foi criada com os pais e } 11 \text { irmãos. O pai era funcionário (gerente) de um comércio no qual } \\
\text { vendia borracha (látex), café Castanha do Pará e peixe. Estudou as séries iniciais no Colégio } \\
\text { das Freiras, mas teve os estudos interrompidos pela grande distância entre sua residência e a } \\
\text { escola. Ajudava a mãe nas tarefas domésticas. Brincava com os irmãos e vizinhos. Teve bons } \\
\text { momentos de lazer em família. }\end{array}$ \\
\hline Janaina & $\begin{array}{l}\text { Órfão de pai, foi criada pela mãe. Cursou apenas as series iniciais do ensino primário no } \\
\text { Colégio Maria Auxiliadora. A mãe era costureira e Janaina na adolescência precisava ajudar } \\
\text { nas tarefas domésticas e no trabalho de costura. Tinha alguns momentos de lazer. }\end{array}$ \\
\hline Taynara & $\begin{array}{l}\text { Foi criada com a mãe e seu companheiro. Teve } 4 \text { irmãos. Não frequentou a escola. Enquanto } \\
\text { os pais iam para a roça, juntamente com os irmãos cuidava dos afazeres domésticos. Viajava } \\
\text { de barco com o padrasto e desfrutava de passeios nas praias de rio. Teve uma educação } \\
\text { rigorosa, mas com acesso ao lazer. Criava brinquedos com elementos da natureza. Depois de } \\
\text { casada teve acesso a escolaridade, em casa com pessoas que a ensinavam. }\end{array}$ \\
\hline
\end{tabular}

\section{Análise e Discussão}

Apesar deste estudo não pretender tratar com profundidade dos aspectos

socioculturais das mulheres da Amazônia, e ter como foco principal as manifestações de

lazer; estes primeiros conceitos virão à tona na medida em que se faz necessário

mencionar o contexto em que viviam as mulheres depoentes; e, principalmente como

viviam. Seguindo o que diz Oliveira (1999) ao se abordar aspectos relativos à idade 
Ivete de Aquino Freire, Ramón Núñes Cárdenas, Manifestação de Lazer na História de Vida de Idosas... Rosa de Luz A. Dos Reis Miranda Sá,

Ednes P. Dos Santos Souza e Paola Lima Tristão

adulta são importantes que sejam contextualizados na discussão, de que adultos se está fazendo referência. Para esta identificação se fará uma passagem pelos aspectos sociais, políticos, econômicos e culturais da época, a fim de contextualizar o cotidiano das mulheres depoentes. É deste cotidiano, que emergem ou não as práticas de lazer.

A partir das entrevistas foi possível observar que, conforme a literatura (OLIVEIRA, 1999; ALVES e MARCELLINO, 2010), nem sempre a idade era o fator principal para que as mulheres fossem consideradas adultas. O casamento e os filhos, que em alguns casos vinham precocemente, foram os fatores que abriram as portas para a maturidade, a exemplo de Jurema que foi mãe solteira aos 16 anos; e Aracy e Anahi que casaram com esta mesma idade.

Foi quando eu trabalhei já, lá (No Seringal), foi aí que eu comecei namorar. Aí teve um, namorei, namorei, namorei até com um primo meu. Eu namorei que acabei me emprenhando dele. E não casei nem nada, teve um filho que ele, que era essa que é a (Diz o nome da filha), com ele (Jurema).

Jurema teve seu primeiro filho aos 16 anos, e assumiu a condição de mãe solteira. De acordo com Levy (2009), nas famílias de estratos socioeconômicos mais altos, o defloramento e crimes como a sedução e o estupro eram vistos como violência moral ao pai da vítima e contra a honra da família toda. Se o crime fosse de sedução, a pena era indenizatória; e de prisão, se o estupro (sedução) fosse por violência e rapto. Ocorre que Jurema teve uma infância e adolescência com privação no atendimento de diversas necessidades, conforme demonstrado na Figura 1. Não conheceu seus pais e nem avós. Teve uma irmã e duas tias como referência familiar consanguínea. Na primeira infância morou com a irmã e mais tarde foi entregue em adoção informal para uma família de desconhecidos. Nesta época, era comum famílias mais abastadas economicamente "pegarem" crianças e adolescentes pobres para assumirem os trabalhos 
Ivete de Aquino Freire, Ramón Núñes Cárdenas, Manifestação de Lazer na História de Vida de Idosas... Rosa de Luz A. Dos Reis Miranda Sá,

Ednes P. Dos Santos Souza e Paola Lima Tristão

domésticos em troca de casa, comida e vestuário. No caso de Jurema, esta não teve acesso à escola e foi explorada pela família que a "adotou". Ela era a responsável por todos os labores domésticos além de trabalhar na roça.

Ainda na temática do defloramento e crime de sedução e estupro, segundo Levy (2009), ocorrido o desvirginamento, o homem era obrigado a casar, cujo matrimônio dava-se às pressas. Também havia casos em que o homem era obrigado, por sentença judicial, a pagar um dote à prejudicada. Tal sentença foi ainda observada em Salvador em 1972 (AZEVEDO apud LEVY, 2009).

Entretanto, com sua trajetória de vida e condição social, é compreensível que Jurema não contasse com a família ou o poder público para apoiá-la e acolhê-la nesta nova condição. Criou sua filha sozinha, trabalhando de lavadeira e como empregada doméstica em casas de família, desta vez com remuneração, ainda que em caráter informal.

Todas as depoentes foram casadas, inclusive Jurema que contraiu matrimônio aos 51 anos. Nos casos de Aracy e Anahi que casaram com 16 anos, quando considerado o fator idade, as fases da adolescência e maturidade se confundem. Descreve Levy (2009) que na área rural de Bofete, no final da década de 1940, a idade mais comum para se casar era de 15 a 16 anos para as mulheres, com limite inferior de 13 e superior de 20 anos, sendo que depois dos 30 era difícil arranjar casamento para ambos os sexos.

Dentre as depoentes, apenas Iracema mencionou que não escolheu o seu marido, sendo esta uma decisão da família que a criou. Iracema foi entregue pela mãe, em adoção, a uma família Turca que morava no Brasil. A mesma residiu com esta família até se casar, em 1950, com 20 anos. A não escolha do marido, conforme aconteceu com 
Ivete de Aquino Freire, Ramón Núñes Cárdenas, Manifestação de Lazer na História de Vida de Idosas... Rosa de Luz A. Dos Reis Miranda Sá,

Ednes P. Dos Santos Souza e Paola Lima Tristão

Iracema, era um fenômeno comum entre as classes socialmente privilegiadas no período colonial no Nordeste (LEVY, 2009). Complementando esta ideia, Mambrini (2010) afirma que no Brasil, até o final da década de 30 as meninas tinham seu casamento arranjado pela família. Com Iracema esta ocorrência se dá duas décadas após supostamente este tipo de fenômeno já haver sido extinto.

Todas as depoentes tiveram filhos. O número de filhos paridos, quando comparado com os dias atuais, é elevado, acompanhando a cultura daquela época. Janaína, por exemplo, teve 10 filhos; Anahí e Iracema tiveram 13, respectivamente. Este dado encontra-se em conformidade com o que diz a literatura quando afirma que na década de 40, até 50, a média de filhos era de 8 a 10 por casal (DEPARTAMENTO DE VIGILÂNCIA, PREVENÇÃO e CONTROLE das IST, do HIV/AIDS e das HEPATITES VIRAIS, 2006).

Dentre as 9 depoentes, 3 tiveram filhos falecidos ainda na infância (Iracema, Taynara e Yara), o que parece ser um fato bastante comum na época considerando as condições sanitárias da cidade de Porto Velho, conforme apresentado mais adiante.

Tainá foi a única depoente que concluiu os estudos e teve uma profissão. Contava com a presença e auxílio da mãe e uma adolescente. Esta última morava com a família, para ajudar a cuidar dos labores domésticos e das crianças.

Trabalhava. Eu comecei a trabalhar em 50, em escola. Sempre lecionei, sempre professora. As crianças ficavam com minha mãe e uma moça sempre tinha em casa (Fala baixinho). Foi antes de me formar eu comecei trabalhar. Eu formei em 51 e comecei a trabalhar em 50, ou antes porque eu trabalhei na divisão de obras na época era divisão, não era a secretaria. [...]. Olha sempre, eu sempre morei com a minha mãe minha mãe, né? Minha mãe faleceu em 79. Tinha minha mãe, a gente sempre tinha uma pessoa conosco e naquele tempo era fácil conseguir uma pessoa pra a gente ter em casa, né? Sempre tinha alguém em casa, tinha lavadeira (Tainá). 
Ivete de Aquino Freire, Ramón Núñes Cárdenas, Manifestação de Lazer na História de Vida de Idosas... Rosa de Luz A. Dos Reis Miranda Sá,

Ednes P. Dos Santos Souza e Paola Lima Tristão

A exceção de Tainá e Iracema, todas as mulheres da pesquisa tiveram momentos ou toda a maturidade de privação. A presença do trabalho foi uma constante na vida destas mulheres, e frequente no discurso das mesmas. Somente Iracema nunca trabalhou. No labor das demais predominavam os trabalhos pesados, em extensas jornadas na roça, de empregada doméstica e lavadeira.

Trabalhava minha filha. Toda vida eu trabalhei muito; Quando eu saí da casa dos meus pais. [...]. Lavava roupa, criava galinha. [...]. Foi assim, serviço de, de roça de, de fazer as coisas assim (Anahi).

Eu trabalhei primeiro no, na, no campo, no campo mermo, roçando lá, depois nós trabalhamo. Aí quando foi eu passei um ano, né? Nesse serviço de Campo. Aí tinha um chefe que gostava muito de mim, aí ele disse, eu vou arrumar serviço pra ti fora daqui. Aí ele arranjou já pra me botar numa casa de farinha, só para descascar mandioca, pro pessoal fazer farinha. Aí foi que eu sai do Campo. Aí eu fui trabalhar lá na farinha, aí lá na farinha eu trabalhei um bocado de tempo, depois eu saí, foi o tempo que eu vim já pra Manaus de novo, pra Santarém de novo, aí e nós viemos para cá em 51 (Para Porto Velho) (Jurema).

Aí, eu fui trabalhar lá no (Cita o nome da escola que foi trabalhar). É, lavava roupa pra fora (Expressão usada na região para explicitar o trabalho de lavadeira) e... trabalhava de noite e inda servia de faxineira. Quando tinha casa pra fazer limpeza, eu ia, né? (Yara).

Grande parte do trabalho destas mulheres não era e ainda não é, em alguma medida valorizado como atividade produtiva, uma vez que se trata de práticas ilegais de trabalho, fora da qualificação social de rendimento, geração de riquezas e lucro.

A exceção de ausência de prática laboral no início da vida adulta se deu com Aracy. Nesta fase da vida, a mesma estava casada; não estudava e nem trabalhava porque o marido não permitia.

Tinha, tinha muita vontade de estudar e naquela época era tudo fácil aqui assim quer estudar vá e até trabalho. Eu tava, nem com 18 anos, Dona (Cita o nome da diretora de uma escola) mandou me chamar. Eu fui lá ela falou: você não quer trabalhar? Não, a vontade eu tenho, mas meu marido não deixa estudar não, mulher minha não sai de casa (Aracy). 
Ivete de Aquino Freire, Ramón Núñes Cárdenas, Manifestação de Lazer na História de Vida de Idosas... Rosa de Luz A. Dos Reis Miranda Sá,

Ednes P. Dos Santos Souza e Paola Lima Tristão

Mas a realidade de Aracy mudou. Com 6 anos de casada, ficou viúva e passou dificuldades com os 7 filhos, baixando o padrão de vida que tinha. Demorou meses para começar a receber a pensão do falecido marido; que por sua vez, não era suficiente para o sustento da família. Trabalhou como lavadeira e empregada doméstica em várias casas de famílias.

[...] eu trabalhei lavando roupa para fora, saia assim de casa em casa. Eu só nunca trabalhei assim, é o único canto que eu trabalhei o dia todo foi nas irmãs (Com as freiras). [...]. Trabalhei três meses na beira de um tanque lavando roupa, ia para casa tão cansada, tão cansada, que eu chegar em casa, começou a dar (Não conclui). Lá era uma mistura de Kiboa com não sei o quê (Referindo-se ao produto de limpeza que usava), com não sei o quê, que a gente ficava com os pé dentro da água o dia todo. Dava aquela frieira cerca que chama, né? Coçava tanto, tanto, que eu chegar, dava febre. Eu não aguentei, eu deixei (Aracy).

Igual a algumas famílias pobres da atualidade, naquela época os filhos de Aracy e Apuana na medida em que iam crescendo, passavam a trabalhar precocemente, em caráter informal, para ajudar nas despesas da casa ou mesmo para financiar e garantir alguns momentos de lazer.

Pois é quando ele morreu ( $\mathrm{O}$ marido) fiquei assim: eu era o pai e a mãe dos sete, né? A (Diz o nome da filha) nunca deu... Já, já tinha 14 anos, né? Aí começou a trabalhar estudava, trabalhava. A (Diz o nome da outra filha) também. [...] saia pra procurar serviço, aí o pouquinho que ela ganhava, ela me ajudava, né? (Aracy).

Aí, ele ia brincar. Não tinha como ele (Referindo-se ao filho) comprar as coisas, ir num cinema. Então em casa tinha um pé de goiabeira ele juntava as goiaba e ia vender pra pagar o cinemazinho dele, comprar uma revista. Era assim a nossa vida (Apuana).

Após 14 anos, na condição de viúva, Aracy casou-se novamente e teve mais 3 filhos, totalizando 10 filhos paridos. A partir daí iniciou no trabalho formal na função de zeladora até se aposentar. 
Ivete de Aquino Freire, Ramón Núñes Cárdenas, Manifestação de Lazer na História de Vida de Idosas... Rosa de Luz A. Dos Reis Miranda Sá,

Ednes P. Dos Santos Souza e Paola Lima Tristão

Ainda durante a fase de maturidade das depoentes, era comum as pessoas mais abastadas economicamente pedir para criar os filhos daquelas com menor poder aquisitivo (conforme já mencionado, algumas depoentes foram dadas em adoção durante a infância). Mas mesmo frente às dificuldades Aracy criou seus 10 filhos.

Foi. Ainda bem que a gente tinha uma casinha, né? A casa, não pagava aluguel. Aí, eu, elas tinha a gente pedir. Todo dia chegava, gente, me dê uma filha sua. Eu não estou passando bem, não, mas eu morro agarrado com meus filhos, mas não dou um filho meu. Não dou! (Aracy).

$\mathrm{Na}$ maioria das residências destas mulheres verificava-se precariedade no atendimento de diversas necessidades. O abastecimento diário das casas com água potável, que hoje é algo simples na localidade, naquela época era um verdadeiro desafio.

(Não havia água encanada). Não. A gente carregava a água do poço, quando não, da beira do rio, subindo ladeira com as latas na cabeça, os balde.[...]. Morava na casa do mesmo jeito (Do mesmo jeito da infância). De palha, coberta de palha, cercada de palha, chão batido (Apuana).

Aqui mesmo em Porto Velho, lá tinha Igarapé que chamava em Igarapé dos Padre. Lá em cima (Sinaliza com a mão) tinha um Igarapé que chamava Igarapé dos Padre. Lá a gente ia lavá roupa. Era. [...]. Não, não, não tinha água e nem luz, era luz de vela.[...]. Era. Os meninos vieram buscá água, buscá água lá na Carlos Gomes (Jurema).

Ah! Não. Eu passei muito tempo carregando água no poço. Era. Todo mundo tinha poço. Aí eu ia buscar água, que elas, lata na cabeça, para dá banho nas crianças e almoço, encher as vasilhas (Aracy).

(Sobre água encanada na residência). Tinha nada (Dando ênfase). Pegava era do riacho. (Sinaliza com a mão explicando a localização do riacho). Aí, nessas Pedrinha (Nome de um bairro), agora tá tudo fechado (Taynara). 
Ivete de Aquino Freire, Ramón Núñes Cárdenas, Manifestação de Lazer na História de Vida de Idosas... Rosa de Luz A. Dos Reis Miranda Sá,

Ednes P. Dos Santos Souza e Paola Lima Tristão

Para algumas mulheres, a água do poço, dos igarapés e rios não era utilizada para lavar as roupas. Para a realização desta tarefa elas iam ao Parque dos Tanques7.

(Sobre o parque dos Tanques). Ficava muito longe. Lá só ia lavá, lavá. Juntava roupa da semana, para ir com aquela bacia desse tamanho (Demonstra com os braços). Eu fiquei quase aleijada. Que às vezes a gente vinha com roupa quase molhada, né? De noite eu não podia dormir. Quando o sol tava bom, secava, né? Era um sofrimento muito grande (Aracy).

Apesar da água ser um bem de primeira necessidade, sendo utilizada fundamentalmente no dia a dia para o preparo de alimentos, para beber e higiene em geral, este serviços básico não era ofertado a toda população. O mesmo ocorria com a luz elétrica.

(Se tinha água encanada na residência). Não, não, não tinha água e nem luz, era luz de vela (Jurema).

Tinha nada (Referindo-se a água encanada). Pegava era do riacho". [...]. Aí, comecei trabalho. Olha, levantava de madrugada, cedinho ia pra lá mais minha vizinha lavá roupa chegava aqui. [...]. Acendia uma lamparina com querosene num tem, tem um farolzinho, farol. Aí ficava na lua claro da lua. [...]. Ai, que novela essa minha vida (Taynara).

A diferença na oferta dos serviços básicos nas localidades de moradia das depoentes quando comparada com o centro da cidade era tão gritante que Tainá chega a confundir-se se morava ou não no município de Porto Velho.

Olha, em Porto Velho (Referindo-se a zona central da cidade) existia (Referindo-se a energia elétrica), mais aqui não tinha nem energia e nem água encanada (Tainá).

A insegurança não se limitava as dificuldades para acesso a água potável e energia elétrica, mas ampliava-se também na precariedade das construções das

\footnotetext{
${ }^{7}$ Espaço público localizado em área fora dos arredores da cidade, dotado de tanques e torneiras para uso coletivo de lavagem de roupa.
} 
Ivete de Aquino Freire, Ramón Núñes Cárdenas, Manifestação de Lazer na História de Vida de Idosas... Rosa de Luz A. Dos Reis Miranda Sá,

Ednes P. Dos Santos Souza e Paola Lima Tristão

residências. A pobreza das casas era refletida nos tipos de materiais utilizados na construção.

Que era como camburão de asfalto, o beral, né? (Referindo-se a sua residência)[...]. Assim, redonda du, du da taperinha era lençol Santista (Marca do tecido) era a nossa parede. Fogão eu fazia carvão daqueles pauzinho do mato, né? Quando agente cozinha. E sofri. Sofri mesmo. [...] minha casa (Falou baixinho) tenho até vergonha de dizer, era de furquilha (Forquilha: ramo de árvore ou arbusto que se bifurca, com o formato aproximado da letra Y) de pau do mato do igapó (Tipo de vegetação característica da floresta Amazônica). Aí em cima era palha, pra poder sair do aluguel, [...] só tinha (Não compreensível), malária e tudo que não prestava (Taynara).

Mas a minha casa era de taipa. [...]. É uma casa que é rodeada de o telhado é coberta de palha e é rodeado com unssss paus assim (Demonstra com as mãos) e colocado barro, barro mole e colocado ali e fazia a parede, era ali (Explicando o que é uma de taipa) (Yara).

Minha casinha era de cerca, de madeira de, e tálbua, e coberta de palha (Anahi).

Conta Perrot (1989) que sob forte influência do século XIX a vida das mulheres de classes econômicas mais favorecidas residentes nas cidades da Amazônia, durante o ciclo da borracha, era distinta daquelas de classes menos privilegiadas economicamente. Entretanto, pela fala das depoentes, constata-se que esta realidade permaneceu mais além do que relata o autor. A situação socioeconômica e inacessibilidade aos serviços públicos básicos de água, energia elétrica e condições dignas de moradia destas últimas, conduzem a interpretação de que as mesmas viviam um cotidiano bastante distinto ao das mulheres urbanas.

As dificuldades financeiras também são retratadas por Taynara ao falar sobre a precariedade na alimentação da família. A pobreza econômica, as condições de insalubridade da região, da localidade e das residências, vinculadas ou não a falta de saneamento básico, como não poderiam ser diferentes, refletiam na saúde da população, em especialmente das crianças. 
Ivete de Aquino Freire, Ramón Núñes Cárdenas, Manifestação de Lazer na História de Vida de Idosas... Rosa de Luz A. Dos Reis Miranda Sá,

Ednes P. Dos Santos Souza e Paola Lima Tristão

Passeiii (Fala dando ênfase) dificuldade mermo. Uma lata de sardinha nóis passava uma semana e não, terminava todo mundo doente de malária. Era tanta coisa. [...]. Minha filhinha quase morre de malária. Meus filhos tudo doente. Mana, minha vida foi uma novela. Eu, eu, já trabalhando peguei malária. Fui pro hospital. [...]. Sofri, sofri mana (Taynara).

Conforme dito anteriormente, a maioria das depoentes residia fora na zona central da cidade; em bairros sem nenhuma infraestrutura de serviços básicos. Entretanto, segundo os historiadores a partir do período entre 1890 a 1920, a cidade de Porto Velho contava com infraestrutura como eletricidade, sistema de água encanada e esgotos, museus e cinemas. Tudo construído a partir da exploração do látex na região Amazônica (LEANDRO, 2014; SOUSA, 2017; PORTAL DA AMAZÔNIA, 2017). Como residiam na periferia da cidade, possivelmente as depoentes viviam um cotidiano distinto ao dos moradores da zona central da cidade.

De modo indireto algumas idosas da pesquisa dão a entender que viveram momentos de violência ou de abandono em seus matrimônios. Algumas deixam claro que passaram por sérias dificuldades com seus companheiros.

Eu já tinha separado do primeiro marido porque ele quis me matar, né? E pegar meu menino. Aí eu fugi dele. Aí, depois eu me juntei com esse outro. Aí ele, eu ia trabalhá, deixava a criança. Ele arrumou uma amante e fazia conta no meu nome (Risos) pra mim pagar, né? Enrolada a minha vida. (Risos) (Apuana).

Minha filha, vamô, pá, pá incurtá história. Vamo sê fran, vamo, vamo falar direitinho o negócio. O meu jogo (Risos). Meu marido me deixou (Incompreensível) depois de cinco filhos e eu criei mais um (Adotou). Que veio de, sob encomenda (Yara).

Com relação a separação, no evento com Yara, constata-se o abandono da família por parte do marido; e no caso de Apuana, esta teve que fugir do cônjuge que a ameaçava de morte. As famílias chefiadas por mulheres são em muitos casos decorrente entre outros aspectos, de abandono por parte do parceiro. Não raro essas mulheres 
Ivete de Aquino Freire, Ramón Núñes Cárdenas, Manifestação de Lazer na História de Vida de Idosas... Rosa de Luz A. Dos Reis Miranda Sá,

Ednes P. Dos Santos Souza e Paola Lima Tristão

foram vítimas de violência doméstica em suas mais variadas vertentes, incluindo-se a "invisível", aquela que não deixa marcas exteriores, mas sequelas profundas em relação à sua autoestima e à busca ou reconstrução de sua identidade como mulher, como cidadã e aos preconceitos decorrentes da relação de gênero (PINTO, 2011).

Aracy, por exemplo, que casou ainda adolescente, conta que ficava em casa sozinha enquanto seu marido saia para se divertir.

É. Aí eu ficava, que ele saía muito Iá, pra (Incompreensível) pás farra dele, que ele tomava uns [Referindo-se a que ingeria bebida alcoólica] e eu ficava só. Não ia na casa de vizinho (Aracy).

As atividades de lazer das depoentes na maturidade estavam condicionadas a diversos fatores, que ao mesmo tempo são limitadores, conforme afirma Marcelino (1993). Quase sempre a excessiva carga de trabalho, caracterizada pelas múltiplas atividades que exerciam simultaneamente, restringia as atividades de lazer. Neste caso, se inclui dupla ou tripla jornada de trabalho. Conforme afirma Spindola (2017), esta rotina de labor de algumas depoentes, era uma prática feminina de trabalho que se assemelha aquela que teve inicio entre os séculos XVIII e XIV.

Não, Não (Dizendo que não usufruía de momentos de lazer). Não, porque eu trabalhava. Eu trabalhava em fábrica de tecelagem. Eu trabalhava a noite e lavava roupa pra fora de dia. Minha vida foi muito, muito pesada. [...]. [...] também, tomei conta duma, duma boate que era boate como é que se diz (Pensando) que tinham as mulheres que iam pro quarto com os homens e eu tomava conta, eu lavava, arrumava tudo por lá. [...]. Eu não tinha lazer. Era só trabalhar e cuidá das coisas. Trabalhar no roçado, às vezes pra eu ir em uma festa eu ia, mas eu ia vender. Fazia bolo de mandioca e ia vender bolo, vender suco pra arrumar um dinheirinho (Apuana).

Nem lembrava dessas coisas (Referindo-se a lazer). Era só mermo fazer as coisas e pronto. Trabalhá, limpá casa, lavá roupa, fazer essas coisas (Jurema).

Não (Dizendo que não tinha lazer nesta etapa da vida). Tinha não. Só vivia em casa mermo. [...]. Não, só isso mermo. Só brincadeira pouca. Carregá água na cabeça. Lá dá, de frente da igreja (Janaina).

Aí, eu fui trabalhar lá no Carmela Dutra (Nome de uma escola). E... lavava roupa pra fora e... trabalhava de noite e inda servia de 
Ivete de Aquino Freire, Ramón Núñes Cárdenas, Manifestação de Lazer na História de Vida de Idosas... Rosa de Luz A. Dos Reis Miranda Sá,

Ednes P. Dos Santos Souza e Paola Lima Tristão

faxineira. Quando tinha casa pra fazer limpeza, eu ia, né? Era o meu lazer na época. Tinha não (Referindo se ao lazer). Só de casa mermo (Yara).

De lazer, não fazia nada, só trabalhá mesmo. Não, num ia porque não dava tempo, trabalhava muito minha filha. E eu ia sair? Tu sabe que hora eu ia pro meu trabalho? As cinco horas da manhã (Anahi).

Em alguns casos a presença de mulheres em espaços de lazer, não era para divertir-se, e sim para trabalhar, igualmente ocorre na atualidade com a classe mais pobre. O trabalho informal em espaços de lazer é mencionado por Apuana.

Eu não tinha lazer. Era só trabalhar e cuidar das coisas. Trabalhar no roçado, às vezes pra eu ir em uma festa eu ia, mas eu ia vender. Fazia bolo de mandioca e ia vender bolo, vender suco pra arrumar um dinheirinho (Apuana).

Sob forte influência do século XIX, as mulheres moradoras da zona rural da Amazônia durante o ciclo da borracha, para sustentar os filhos ou contribuir com o marido no sustento dos mesmos, enfrentavam longas jornadas de trabalho até mesmo labores mais "pesados" que historicamente considera-se que exigem a virilidade associada ao homem (PERROT, 1989). Yara é um exemplo de mulher cuja trajetória de vida identifica-se com o que diz este autor.

[...] compramos um boi [...]. Ia buscar carvão na mata fechada (Trabalhava com compra e venda de carvão). Os homens ensacavam e botavam na carroça e eu trazia para vender (Trazia para a cidade) (Yara).

O exemplo de Yara acompanha também o que diz Carvalho apud Pinto (2011). Nas camadas mais pobres da população, as famílias chefiadas por mulheres, são em grande parte associadas às situações de vulnerabilidade econômica. A mulher, como único membro adulto do domicílio, é a provedora, além de assumir funções domésticas e o cuidado com os filhos. 
Ivete de Aquino Freire, Ramón Núñes Cárdenas, Manifestação de Lazer na História de Vida de Idosas... Rosa de Luz A. Dos Reis Miranda Sá,

Ednes P. Dos Santos Souza e Paola Lima Tristão

Com Taynara, observa-se também uma realidade de muito trabalho, coragem e perseverança na luta pela sobrevivência. Entretanto, esta contava com a participação do marido.

Eu digo que vou dá pro meus filho aquilo que eu não teve pra mim, vou dá pros meus filhos! Tenho fé em Deus. Rastei sandalinha na rua empurrava um carrinho vendendo as coisas que eu fazia todo tempo. Gostava de fazer, né? Os salgadinho, os docinho. Tudo pra vendê, pra tirá dinheiro pra ajudá meus filhos. Meu marido trabalhava, mas não ganhava essas coisas (Taynara).

A informalidade no trabalho, tanto com patrão quanto sem patrão, é caracterizada pela falta de vínculo com um empregador; ocorre quando o trabalhador não tem nenhum direito ou beneficio trabalhista, conforme citam Meneguin e Bugari (2008). Esta informalidade foi elemento significativo na realidade de grande parte das depoentes na primeira etapa da maturidade. $\mathrm{O}$ fato de não ter vínculo formal favorece a interpretação, por parte das depoentes, de que não trabalhavam de fato, conforme se pode observar no depoimento de Jurema.

Não. Aqui não trabalhei em canto nenhum (Afirmando que não trabalhou quando chegou a Porto Velho). Lavei foi roupa, só lavar roupa, ainda trabalhei na casa de família uma vez. Não duas vez trabalhei na casa de família. [...] quando eu sai de lá passei um tempo que trabalhei num bar, tinha um barzinho lá no meio da rua. [...] aí eu fiquei naquela... aí, é lavá roupa, cuidá da casa e...(Sobre o pagamento). Por mês e por peça, aí já lavava pra ganhar dinheiro. No Igarapé, Igarapé (Local que lavava as roupas) (Jurema).

Igualmente Jurema, pela informalidade de suas atividades laborais, Yara também não considerava trabalho vender carvão, após trazer este produto pela mata, em uma carroça puxada por um boi. Denota-se esta visão quando afirma que era "do lar", conforme destacado mais adiante.

Algumas idosas mencionaram seus processos de inserção no mercado de trabalho formal. Este dado aproxima-se com o relato de Versiani e Suzigan (1990) 
Ivete de Aquino Freire, Ramón Núñes Cárdenas, Manifestação de Lazer na História de Vida de Idosas... Rosa de Luz A. Dos Reis Miranda Sá,

Ednes P. Dos Santos Souza e Paola Lima Tristão

quando afirmam que nos anos 70, observou se uma expansão da economia, crescente urbanização e ritmo acelerado da industrialização. Estas características configuram um momento de grande crescimento econômico, favorável à incorporação de novos trabalhadores, inclusive do sexo feminino. Por outro lado, Bruschini (1994) destaca que neste período além de marcantes transformações sociais ocorridas no país, constatou-se também o crescimento da participação feminina no mercado de trabalho brasileiro. Entretanto, Brito e Souza (2005) assinalam que nesta ocasião se deu um crescimento extremamente desequilibrado do ponto de vista espacial e social, posto que se vislumbrasse um desenvolvimento mais concentrado nos estados do Rio de Janeiro e São Paulo. Este desenvolvimento pontual acentuou os desequilíbrios regionais; uma vez que não conseguia gerar o número de empregos que atendesse ao crescimento da sua força de trabalho. Verifica-se pelas falas das entrevistadas que estas foram inseridas no mercado de trabalho formal em momentos anteriores aos anos 70, o que pode significar neste caso que, de algum modo, o contexto nacional pouco influenciou no cotidiano laboral das mesmas.

Não. Antes era do lar. Foi em 1958 que comecei a trabalhar na Samaritana (Uma escola de Porto Velho). Trabalhei um ano e pouco e depois passei a ser inspetora (Yara).

Eu trabalhei desde 58. de lá me aposentei (Janaína).

Trabalhava. Eu comecei a trabalhar em 50 em escola. Sempre lecionei. Sempre professora (Tainá).

Aí arranjei trabalhei no [...]. Fui trabalhar lá de merendeira. [...]. Ó, sei que passei 35 anos trabalhando. Não tô nem lembrando da data; mais meados de 1960. É. É. Eu trabalhei 35 anos (Taynara).

Um estudo de Belo (2013) apontou que no período produtivo das idosas, as lutas das mulheres ainda eram circunscritas a um universo minoritário. Esta realidade não coaduna com o cotidiano das depoentes na maturidade. Das 9 entrevistadas, apenas 3 
Ivete de Aquino Freire, Ramón Núñes Cárdenas, Manifestação de Lazer na História de Vida de Idosas... Rosa de Luz A. Dos Reis Miranda Sá,

Ednes P. Dos Santos Souza e Paola Lima Tristão

não precisaram trabalhar na adolescência e/ou na infância. A maioria, em algum momento de suas vidas foram inseridas no mercado de trabalho informal e formal, apesar da pouca formação escolar. Algumas delas, a exemplo de Taynara, sequer frequentaram a escola. Outras tiveram seus estudos formais interrompidos ainda na meninice.

Conforme observado, foi frequente no discurso das idosas, quando se perguntava sobre o lazer destas, a comunicação da inexistência desta prática, frente o cotidiano laboral, ao qual eram submetidas. Chama a atenção que não se verifica na fala das mesmas, qualquer traço de questionamento relativo ao processo de exclusão ao qual eram submetidas. Relata Silveira (2015) que somente na década de 1960, eclodiram os grandes movimentos sociais de contestação às diferenças sociais; movimentos contra a subalternidade e exclusão das mulheres do poder, e pela autonomia e direitos destas, nos principais centros urbanos do Brasil e do mundo. Ocorre que nesta época, as localidades mais longínquas, a exemplo da Amazônia e em especial a cidade de Porto Velho, encontravam-se bastante isoladas geograficamente dos grandes centros do país, portanto, sem acesso aos movimentos sociais e as discussões geradas em torno destes temas. Assim, o discurso feminista não chegou de forma igual e nem ao mesmo tempo em todas as realidades. Nesse sentido, a dinâmica no cotidiano das mulheres era outra. No caso das depoentes, esta realidade aponta para práticas feministas por necessidade, independente dos movimentos revolucionários que ocorriam nos grandes centros culturais do Brasil e do mundo. As conquistas alcançadas no mundo do trabalho e a relativa emancipação, não decorriam do fortalecimento do feminismo e/ou de outros movimentos políticos da época, mas de uma necessidade real de sobrevivência e manutenção dos filhos. 
Ivete de Aquino Freire, Ramón Núñes Cárdenas, Manifestação de Lazer na História de Vida de Idosas... Rosa de Luz A. Dos Reis Miranda Sá,

Ednes P. Dos Santos Souza e Paola Lima Tristão

Os movimentos sociais de contestação às diferenças sociais entre homens e mulheres, apontam que mesmo em uma época em que o espaço no mercado de trabalho para o gênero feminino era restrito, algumas mulheres transpunham as barreiras do papel de ser apenas esposa, mãe e dona do lar (SILVEIRA, 2015). Ainda que aparentemente sem a influência dos movimentos sociais feministas, algumas depoentes atuavam como mantenedoras do lar; e em alguns casos sendo elas as únicas provedoras da família, desmistificando o discurso dominante da mulher vulnerável.

A maioria das depoentes cita que devido às múltiplas atividades laborais que exerciam simultaneamente para suprir as necessidades de manutenção da família, não tinham tempo para desfrutar de lazer. Essa visão, hierarquiza atividades e aponta o lazer como mero acessório do trabalho, conforme citam Alves e Isayama (2006). Também lembram Alves e Marcellino (2010) que o sistema capitalista pode anular as outras dimensões de expressão das pessoas por enxergar o trabalho como principal ocupação. O lazer acaba sendo entendido como atividade de tempo livre não séria e vazia (ALVES e MARCELLINO, 2010). Ocorre que no caso das depoentes menos abastadas economicamente, perante a demasiada carga de trabalho, a anulação do lazer como expressão da vida humana não se dava pelo fato de entenderem o trabalho como principal ocupação, mas, sobretudo pela falta de tempo ou energia para desfrutar de qualquer outra atividade que não fosse relativa à subsistência.

Depreende-se na fala das idosas, que a situação socioeconômica foi um elemento importante na definição das suas práticas de lazer e de ausência de lazer. A maioria delas era de família com baixas condições econômicas. Foram acostumadas ao trabalho pesado, com dupla, tripla ou mais jornada de trabalho; habituadas a lavar as roupas nos rios, carregar lata de água na cabeça; a exceção de Tainá que era professora e tinha uma 
Ivete de Aquino Freire, Ramón Núñes Cárdenas, Manifestação de Lazer na História de Vida de Idosas... Rosa de Luz A. Dos Reis Miranda Sá,

Ednes P. Dos Santos Souza e Paola Lima Tristão

vida estável financeiramente junto com o marido; e Iracema que nunca precisou trabalhar. Portanto, as práticas de lazer da maioria destas mulheres, como não poderiam ser diferentes, reproduziam as desigualdades sociais.

Apesar da Amazônia se tratar de um contexto diferenciado e serem parcos os estudos voltados ao lazer nesta realidade, uma publicação de Bruhns (1997) contribui para a análise desta questão. Cita o autor que entre as dificuldades ao acesso do lazer, pelas camadas desfavorecidas, situa-se a necessidade de cumprir horas-extras no trabalho, preços inacessíveis dos ingressos para apreciação de eventos de caráter cultural, além de dependência de transportes coletivos e a longa distância do lar para os centros de lazer. Na realidade das mulheres investigadas, os afazeres destas, iam além do cumprimento de horas extras. Se por um lado elas não tinham tempo para pensar em lazer, suas atividades iam se naturalizando no cotidiano frente às inúmeras tarefas que desempenhavam para a sobrevivência da família, conforme cita Jurema, que trabalhava para garantir o sustento da família e o atendimento as tarefas do lar.

Com Tainá se observa a existência de momentos de lazer em família.

Ah! Tinha (Afirmando que tinha lazer). A gente passeávamos bastante todo domingo. Ele (O marido) pegava o carro, a gente saía é, pra rodar Porto Velho todinha. Ou então ia pra banhos, pra viagens, viajava pra Guajará-Mirim (Município do estado de Rondônia) (Tainá).

Mas, conforme visto anteriormente, a realidade de Tainá não é acompanhada pelas demais depoentes. As dificuldades econômicas, aliadas às precárias condições de infraestrutura da cidade refletem a realidade das poucas opções de lazer destas mulheres, na época da maturidade, na cidade de Porto Velho. Jurema, conforme destacado anteriormente, depõe que sequer tinha tempo para pensar em tais possibilidades, frente aos inúmeros afazeres a cumprir. 
Ivete de Aquino Freire, Ramón Núñes Cárdenas, Manifestação de Lazer na História de Vida de Idosas... Rosa de Luz A. Dos Reis Miranda Sá,

Ednes P. Dos Santos Souza e Paola Lima Tristão

Em aparente contradição com o que foi narrado anteriormente, as depoentes fizeram menção a algumas práticas de lazer. Esta provável incoerência é analisada por Sartori (2013). Para a autora, a

[...] síntese de uma trajetória nem sempre é linear, ou coerente das múltiplas representações. Devemos compreender que os consensos se refazem e desfazem a todo o momento. Ou seja, o que aceitamos anteriormente, podemos negar hoje, e podemos também, difundir atualmente, o que foi renegado no passado. A História é um fluxo contínuo do cotidiano que não cessa, mas que se rompe, se desfaz e se renova a todo instante (p. 97).

As vivências do trabalho árduo são tão fortes nas lembranças das idosas que inicialmente ao serem questionadas diziam que não tiveram nenhuma prática de lazer. Possivelmente esta afirmativa se deve as parcas experiências lúdicas das mesmas. Conforme afirma Alves (2007), as possibilidades de vivência do componente lúdico da cultura na vida adulta são restritas. No caso das idosas, é possível que tais restrições tenham impedido de se reportarem, "de pronto" ao pequeno mundo de lazer ao qual tinham acesso durante a maturidade.

Yara e Tainá apontam algumas opções de lazer, entretanto, acessível somente às populações de maior poder aquisitivo a qual elas não faziam parte. Este dado acompanha o que foi dito por Marcellino (2002) sobre os condicionantes ou limitadores do lazer. Também encontra eco no que Bruhns (1997) citou sobre os preços inacessíveis dos ingressos para apreciação de eventos como uma das dificuldades ao acesso do lazer, pelas camadas desfavorecidas. Em ambos os casos o relato diz respeito a barreira socioeconômica, que limita a participação nas práticas de lazer.

Ah, eles tinha a diversões deles (As pessoas abastadas economicamente). Tinha as festa, né? (Referindo-se a pessoas de classe social mais abastada). Tinha os bailes e quem não, num tinha condições não ia pros bailes que eles iam, nera? Que era baile finos, né? Tinha o Bancrévea (Nome de um Clube) aqui perto, mas só era gente, gente fina (Yara) . 
Ivete de Aquino Freire, Ramón Núñes Cárdenas, Manifestação de Lazer na História de Vida de Idosas... Rosa de Luz A. Dos Reis Miranda Sá,

Ednes P. Dos Santos Souza e Paola Lima Tristão

Olha na época tinha cinema, tinha o Cine Brasil; tinha a Praça Marechal Rondon que era o chique aos Domingos e o povo ia passear na praça (Tainá).

Detalhando o que foi dito anteriormente, segundo Marcellino (2002), existem barreiras classificadas como inter e intraclasses de acesso ao lazer. Estas barreiras são elementos que cooperam para o distanciamento da pessoa adulta do lúdico e estão classificadas em três categorias principais: a) a falta de educação para e pelo lazer; b) a situação socioeconômica e, c) a idade. No caso da pesquisa com as idosas encontra-se identificação direta com a primeira barreira, sendo ainda acrescentada outra, que envolve a questão de oferta de espaços pelo poder público.

Complementando o que disse Marcelino (2002), um estudo de Alves (2007) sobre práticas de lazer de adultos mostrou que além da excessiva carga de trabalho, um segundo motivo fundamental que interfere nesta prática, é a falta de educação para e pelo lazer. O estudo detectou que a falta de tempo não é o principal motivo do afastamento, mas, sim, não saber o que fazer durante um tempo disponível. Conforme já demonstrado anteriormente, estes achados não são compartilhados com os resultados ora apresentados sobre o lazer das mulheres da Amazônia no período entre 1949 e 1968.

Taynara cita algumas opções de lazer somente para adultos, mas afirma que preferia usufruir estes momentos com os filhos pequenos e demais parentes.

Tinha (Afirmando que existiam espaços de lazer). Já inventaram o Flamengo (Faz referência ao Clube do Flamengo de Porto Velho). Já tinha o Flamengo, né? [...]. Ah! Sim eu passeava. Tinha aquela fonte de água luminosa, em frente o palácio (Palácio do Governo). Lá levava meus filhinhos pra passear, pra ver. De noite dava tempo. [...]. Eu saia assim, nas casa dos parente que já tinha aqui, né? (Taynara).

As praças eram os espaços mais acessíveis para a população pobre; oportunizava momentos de passeios com os filhos. 
Ivete de Aquino Freire, Ramón Núñes Cárdenas, Manifestação de Lazer na História de Vida de Idosas... Rosa de Luz A. Dos Reis Miranda Sá,

Ednes P. Dos Santos Souza e Paola Lima Tristão

Com uma trajetória de vida de trabalho, Apuanã cita que seus momentos de lazer foram com os filhos já maiores. Estes a incluíam nas ocasiões em que estavam na companhia dos amigos e namoradas.

Às vezes eu ia pra casa dos colegas deles (Colega dos filhos), namorada dele, ou da mãe delas. Assim, saia enquanto ele era rapaz, né? Mas depois que ele casou, aí agente já saia pra outros canto com ele (Apuana).

Apesar das precárias condições de infraestrutura da cidade e do tempo ser gasto prioritariamente nas atividades laborais, fossem no lar ou fora dele, as idosas nomearam alguns tipos de lazer que vivenciaram.

A gente (Ela e o marido), só as vez ia pra uma festa, não? Naquela época já tinha, tinha o Danúbio (Nome de um clube) já (Jurema).

Aí eu conheci um, uma, uma colega aí nós tínhamos uma diversão que a gente ia pra lá pra um negócio dum, como é que se diz (Fala baixinho). Lá no Celso, do candomblé. Era essa a diversão, a gente ia pra lá e tal assistir aí (Yara).

Eu saia assim, nas casa dos parente que já tinha aqui, né? Em Porto Velho eu ia na casa deles; eles iam na minha (Taynara).

O lazer era se juntá os vizinho, sentá na frente e cunversá, contá história (Aracy).

Despois que eu comecei a conhecer as pessoas eu ia pras festa. Lá, de noite, uma vez no mês, duas vezes. A gente, já arrumei as colega, né? [...]. A gente se juntava e ia pras festas. Às vezes eu ia pra casa dos colegas dele (Referindo-se ao filho), da namorada dele, ou da mãe delas. Assim saía enquanto ele era rapaz, né? (Apuana).

Ah! Tinha sim (Referindo-se a diversão). [...]. Nós íamos todo tempo festa. Tinha muito aqui em casa. Todo domingo tinha festa aqui (Risos). Olha, os vizinhos, nós nos reunimos mais na época, na época de São João, e o mês de junho que tinha, isso quando já tinha criança, né? E os vizinhos se reuniam, faziam quadrilha, aqui das crianças (Tainá).

Chama à atenção, a ausência na fala das depoentes, do Estádio Aluízio Ferreira como um espaço de lazer; quer para a prática do esporte, quer para a assistência de espetáculos. Este estádio, localizado na capital do estado de Rondônia, na cidade de 
Ivete de Aquino Freire, Ramón Núñes Cárdenas, Manifestação de Lazer na História de Vida de Idosas... Rosa de Luz A. Dos Reis Miranda Sá,

Ednes P. Dos Santos Souza e Paola Lima Tristão

Porto Velho, fora da zona central da cidade, foi construído em 1957 para práticas de futebol. Foi o primeiro espaço público oficial esportivo da localidade. A disponibilização à sociedade deste espaço de esporte e lazer se deu próximo à década de 1960, momento de grandes reflexões para a sociedade contemporânea conforme já mencionado anteriormente. Na década de 50, algumas mulheres já se destacavam nos espaços de futebol no Rio de Janeiro. Em 1956, Dulce Rosalina se torna a primeira mulher a liderar a Torcida Organizada do Vasco (COSTA, 2016). Anteriormente, na década de 1920, a assistência aos espetáculos de futebol era um luxuoso programa das elites urbanas (FRANZINI, 2005). Pela ausência da menção do Estádio Aluísio Ferreira no discurso das depoentes como um espaço de lazer, nota-se um grande distanciamento entre a Amazônia e a região Sudeste (no caso, Rio de Janeiro), no que diz respeito a participação da mulher nos espaços de futebol.

O não registro do Estádio Aluízio Ferreira como espaço de lazer pode expressar, ainda que de modo inconsciente, as relações de gênero presentes na localidade e no cotidiano das mulheres. Cita Franzini (2005) que o universo do futebol caracteriza-se, desde a sua origem, como um espaço eminentemente masculino, entretanto, esse espaço não é apenas esportivo, mas também sociocultural.

O Estádio Aluízio Ferreira era o único espaço público de lazer disponível em Porto Velho á época de maturidade das idosas. Entende-se espaço público de lazer o que diz Pedroso e Silva, (2011) e Radicchi et al (2015): os espaços esportivos de lazer e educação referem-se às instalações e equipamentos urbanos destinados à prática de atividades físicas e/ou esportivas de caráter espontâneo e livre, presentes em área pública. Os autores consideram ainda espaços públicos locais com algum tipo de infraestrutura esportiva voltada ao lazer, educação ou participação de acesso livre pela 
Ivete de Aquino Freire, Ramón Núñes Cárdenas, Manifestação de Lazer na História de Vida de Idosas... Rosa de Luz A. Dos Reis Miranda Sá,

Ednes P. Dos Santos Souza e Paola Lima Tristão

população e/ou que esteja localizado em instituição pública (escola, ginásio, universidade, estádio, parque, praça).

As depoentes citam as duas praças localizadas no centro da cidade de Porto Velho, como locais de passeios. A gratuidade facilitava acesso a estes espaços, apesar da distância de suas moradias. As companhias das idosas para as atividades de lazer se dividiam entre família e amigos, sendo o primeiro caso o mais mencionado. Compreende-se como lazer em família, acompanhar os filhos pequenos para usufruírem de momentos lúdicos. Seguindo a classificação de Mosquera (1987) pode-se perceber que estas mulheres nas etapas da idade adulta jovem inicial e idade adulta jovem plena tinham suas vivências de lazer atreladas a oferta de momentos lúdicos aos filhos. Entretanto, segundo a literatura, tais vivências não podem ser consideradas lúdicas para as mães, uma vez que o lazer envolve ocupações que possuem certas características como a liberação das obrigações, inclusive aquelas familiares. Desse modo, o tempo em questão, não era um "tempo livre” disponível para elas; e sim, era reutilizado para outras obrigações, neste caso, para atendimento ao lazer dos filhos.

Pode-se afirmar que apesar do lazer ser apontado na literatura como um fenômeno característico da cultura humana, para algumas das depoentes na etapa da maturidade, esta prática somente foi usufruída na idade adulta jovem final, seguindo a classificação de Mosquera (1987). Nesta fase, as idosas já estavam vinculadas ao mercado de trabalho formal, conforme cita Apuana:

Despois que eu comecei a conhecer as pessoas eu ia pras festa. Lá, de noite, uma vez no mês, duas vezes. A gente, já arrumei as colega, né? Nos trabalho. [...] Foi arrumando as colega. A gente se juntava e ia pras festas (Apuana).

Do mesmo modo alguns dos filhos já se encontravam na pré-adolescência ou adolescência; outros na maturidade inicial. Estes fatores contribuíram para que as idosas 
Ivete de Aquino Freire, Ramón Núñes Cárdenas, Manifestação de Lazer na História de Vida de Idosas... Rosa de Luz A. Dos Reis Miranda Sá,

Ednes P. Dos Santos Souza e Paola Lima Tristão

durante a fase adulta, usufruíssem de algumas práticas de lazer como participação a bailes ou desfrutar de programas outros na companhia de amigas.

$\mathrm{Na}$ fala das depoentes, na fase adulta jovem final, vislumbram-se alguns aspectos que delineiam os conceitos atuais de lazer. Um deles, conforme cita Camargo apud Aquino e Martins (2007), é o sentido popular da palavra, relacionando "lazer" a "tempo livre" ou a algum tipo de atividade realizada nos momentos de folga. Com Camargo (1989) entende-se lazer como um conjunto de atividades realizadas num tempo livre subtraído ou conquistado, historicamente da jornada de trabalho profissional e doméstica que interferem no desenvolvimento pessoal e social do individuo (apud AQUINO e MARTINS, 2007). Complementando o que diz Camargo, citam Gomes, Pinheiro e Lacerda (2010), que o lazer associado simplesmente à palavra "tempo livre" está em consonância com uma visão ultrapassada desta prática.

Entre outros pontos, Marcellino (1987) concebe o lazer como um fenômeno social, que dialoga com a sociedade e possibilita o surgimento de valores questionadores que conjecturam mudanças. O mesmo autor, numa publicação de 1995 contribui para compreensão do fenômeno lazer afirmando que tais vivências favorecem a potencialização do desenvolvimento pessoal e social. Complementando estes aspectos, Oliveira (1997) vislumbrou o lazer como uma prática que pode favorecer o questionamento, pontuando que através das práticas de lazer, e por meio delas, os homens podem elaborar críticas a sua vida cotidiana. Seguindo nesta direção, Gomes, Pinheiro e Lacerda (2010) afirmam que o lazer está entre as esferas da vida humana que representa um dos fatores básicos para exercício da cidadania.

Ocorre que, conforme visto no discurso das depoentes, categorias ou expressões constantes da concepção atual de lazer, tais como "desenvolvimento pessoal", "valores 
Ivete de Aquino Freire, Ramón Núñes Cárdenas, Manifestação de Lazer na História de Vida de Idosas... Rosa de Luz A. Dos Reis Miranda Sá,

Ednes P. Dos Santos Souza e Paola Lima Tristão

questionadores que culminam em mudanças" e "exercício da cidadania" não estão presentes nas vivências das mulheres investigadas. Ao contrário, o lazer das depoentes se identifica muito mais com práticas compensatórias, como afirmava Dumazedier e/ou como necessidade humana segundo dizia Bruhns (1997).

As palavras de Gomes, Pinheiro e Lacerda (2010) favorecem o entendimento do duplo papel que pode exercer o lazer do ponto de vista social. Desse modo, apoia a compreensão do distanciamento do lazer das mulheres com relação aos conceitos voltados ao fenômeno, como vivências que em alguma medida potencializam a transformação. Segundo Gomes, Pinheiro e Lacerda (2010), lazer é um fenômeno dinâmico, que apresenta dupla característica: tanto pode reforçar a ordem social quanto possibilitar a criação de algo novo e a transformação da sociedade.

Os escritos de Gomes (2004), também amparam a compreensão teórica das vivências de lazer das idosas na idade adulta jovem final. A autora aborda a tripla função do lazer, ao apresentar suas possibilidades de diversão, de descanso ou de desenvolvimento. As práticas de lazer das depoentes parecem estar em consonância com a possibilidade de diversão. Entende-se desta forma porque percebemos que questionamentos e críticas do cotidiano são aspectos fundamentais para o desenvolvimento pessoal e social; ou dito de outra forma, o desenvolvimento pessoal e social é potencializado através de questionamentos e críticas. Não foi observado na fala das depoentes rasgos de práticas de lazer com viés no desenvolvimento pessoal ou social na perspectiva de formação para a cidadania.

É a atitude do praticante frente às vivências de lazer que atribui uma qualificação a esta prática. A qualidade do lazer está relacionada ao nível de consciência crítica, ativa e transformadora alcançada pelo individuo durante e após sua vivência. São vivências 
Ivete de Aquino Freire, Ramón Núñes Cárdenas, Manifestação de Lazer na História de Vida de Idosas... Rosa de Luz A. Dos Reis Miranda Sá,

Ednes P. Dos Santos Souza e Paola Lima Tristão

lúdicas com estas características que proporcionam ao lazer a possibilidade das pessoas exercerem a plena cidadania. Considerando estes aspectos, e pelo viés do lazer, pode-se inferir que parte destas mulheres teve sua cidadania negada na maturidade.

As atividades de lazer das idosas na fase de maturidade se caracterizavam por três aspectos diferentes. A inexistência (no caso de Iracema) ou descontinuidade à prática; e restrição quanto à variedade e quantidade. A descontinuidade realça na fala das depoentes quando deixam entender que não era destinado um momento específico para o lazer. Compreende-se desta forma quando se localizam na fala das idosas, momentos em que estas negam que tivessem tempo para usufruir de lazer, utilizando como justificativa a falta de tempo frente aos inúmeros afazeres.

A restrição quanto à variedade de práticas decorre de deficiência qualitativa e quantitativa tanto de conteúdo como de infraestrutura e logística. Prevaleciam locais públicos como praças, balneários, clubes e cinema. Alguns espaços, entretanto, apresentavam acessibilidade limitada pelo fato de exigir pagamento.

A precarização do lazer juntamente com a inacessibilidade a direitos sociais básicos, como uma habitação digna, energia elétrica e água potável constatadas neste estudo, aproxima-se ao trabalho de Mendonça et al (2009), sobre o cotidiano de lazer dos moradores do "Santa Rosa", em Campina Grande, na Paraíba. Estes autores, juntamente com outros (a exemplo de MARCASSA, 2004) criticam as políticas sociais brasileiras, dentre elas as do lazer, que se desenvolvem sob a lógica paternalista e assistencialista. Ocorre que as mulheres pobres residentes na região Amazônica, em especial em Porto Velho, no período entre 1949 e 1968 não gozavam de nenhuma política para o setor de lazer e quiçá para nenhum setor social. Somente na década de 80, a Constituição da República Federativa do Brasil de 1988, em seu artigo 6º 
Ivete de Aquino Freire, Ramón Núñes Cárdenas, Manifestação de Lazer na História de Vida de Idosas... Rosa de Luz A. Dos Reis Miranda Sá,

Ednes P. Dos Santos Souza e Paola Lima Tristão

preconizou que o lazer é um direito social de todo cidadão brasileiro, embora até hoje se observe discrepâncias entre a legalidade e a realidade.

Um estudo de Mori e Silva (2010) acompanha os resultados aqui apresentados sobre o lazer de adultos. Tanto no trabalho de Mori e Silva (2010), quanto no presente do estudo, os sujeitos tinham uma árdua rotina de trabalho, além de outras obrigações permanentes que os alijaram de contato com o lazer. Este cotidiano contribui para a dificuldade de compreensão do papel do lazer na vida das pessoas, e, consequentemente para a valorização desta prática.

Mas esta realidade não se deu em todo o Brasil. O estudo de Possamai, Gastal e Negrine (2009) realizado com idosos residentes na Região da Serra Gaúcha/RS, indica que os participantes usufruíram de momentos inesquecíveis de lazer quando estavam na maturidade. Apesar de todas as dificuldades enfrentadas, a exemplo de total falta de estrutura complementar como hospedagem e alimentação nas viagens e do cotidiano diário de trabalho na roça, os mesmos relatam o prazer que encontravam nos momentos descritos como lazer. Apesar de se tratarem de práticas simples e com pouca variedade, os relatos apresentados pelos autores deixam claro que os momentos de lazer foram importantes no cotidiano daquela população; de modo totalmente distinto das mulheres pobres da Amazônia.

Apesar do histórico de trabalho árduo, muitas dificuldades domésticas e privação diversa não se notam na fala das depoentes, traços de amargura, melancolia, ressentimento ou sofrimento. Ao contrário, demonstram atitude de superação mesmo ao falarem de temas delicados. Apuana, por exemplo, sorriu várias vezes ao fazer referências aos atos de violência que sofreu com o antigo esposo. O mesmo ocorreu com Yara ao mencionar que foi abandonada pelo marido. 
Ivete de Aquino Freire, Ramón Núñes Cárdenas, Manifestação de Lazer na História de Vida de Idosas... Rosa de Luz A. Dos Reis Miranda Sá,

Ednes P. Dos Santos Souza e Paola Lima Tristão

\section{Considerações Finais}

A pesquisa estudou as manifestações de lazer de idosas da Amazônia brasileira, residentes em Porto Velho durante a maturidade. Dentre as principais características do universo feminino das mulheres que participaram deste estudo destacam-se o discurso da sobrevivência por uma condição da classe social a qual estavam inseridas. Movidas pela necessidade de sobrevivência, algumas delas assimilaram a cultura do trabalho ainda na infância, passando pela meninice, adolescência e permanecendo na maturidade. Algumas não usufruíram do convívio e do afeto familiar; tiveram verdadeiramente suas infâncias e adolescências roubadas.

$\mathrm{Na}$ maturidade, durante as três subfases, suas atividades cotidianas eram prioritariamente desempenhadas para a sobrevivência da família e o atendimento às tarefas do lar. Tais fenômenos foram observados com maior intensidade na idade adulta jovem inicial e na idade adulta jovem plena, período em que os filhos eram ainda crianças e as depoentes estavam vinculadas a trabalhos informais e diversificados. Já na fase adulta jovem final, observam-se algumas alterações nas quais se destacam a entrada dos filhos na pré-adolescência/adolescência e idade adulta e a inserção das depoentes no mercado de trabalho formal.

Como não poderiam ser diferentes, as práticas de lazer destas mulheres têm profunda relação com o contexto social, econômico e cultural no qual estavam inseridas. O lúdico na vida delas se caracteriza entre a inexistência de lazer (no caso de uma delas na fase adulta jovem inicial e na idade adulta jovem plena) ou a descontinuidade à prática; e restrição quanto à variedade e quantidade. As praças, clubes de festas, cinema e balneários eram os espaços de lazer da localidade. Como nem todos os espaços eram públicos ou próximos das residências das depoentes, o acesso a estes pela maioria das 
Ivete de Aquino Freire, Ramón Núñes Cárdenas, Manifestação de Lazer na História de Vida de Idosas... Rosa de Luz A. Dos Reis Miranda Sá,

Ednes P. Dos Santos Souza e Paola Lima Tristão

mulheres era restrito. Igualmente na atualidade, juntamente com o aspecto econômico, os fatores social e cultural da época também eram condicionadores das vivências de lazer das mulheres. Os grupos de compartilhamento de práticas de lazer das depoentes eram os filhos e amigos dos filhos; e com o avançar da maturidade ficaram restrito aos seus próprios grupos de amigas.

As idosas não nomearam materiais ou equipamentos que tenham sido utilizados nas suas práticas de lazer na idade adulta. Tal ausência justifica-se pela precariedade de infraestrutura e logística dos espaços públicos e culturais disponíveis para o lazer, visualizadas na fala das depoentes.

\section{REFERÊNCIAS}

ALVES, C. O papel do profissional de Educação Física como intermediário entre o adulto e o lúdico. (Mestrado). Faculdade de Ciências da Saúde, Curso de Educação Física, Unimep, Piracicaba, 2007.

; ISAYAMA, H, F. Considerações sobre o lazer na idade adulta. In: MARCELLINO, N, C. Repertorio de atividades por fases da vida. Campinas: Papirus, 2006.

; MARCELLINO, N. C. Adulto e lúdico: atuação do profissional de Educação Física no lazer. Motriz, Rio Claro, v.16 n.1 p.103-112, jan./mar. 2010. Disponível em: http://cev.org.br/biblioteca/adulto-ludico-atuacao-profissional-educacao-fisica-lazer/ . Acesso em 16 Mar 2018.

AQUINO, C.A.B.; MARTINS, J.C.O. Ócio, lazer e tempo livre na sociedade de consumo e do trabalho. Rev. Mal-estar. Subj. V7. N.2. Fortaleza. Set 2007. Disponível: em:http://pepsic.bvsalud.org/scielo.php?script=sci_arttext\&pid=S151861482007000200 013 . Acesso em: 16 Ago 2016.

BELO, I. Velhice e mulher: vulnerabilidades e conquistas. Revista feminismos.Vol.1, N.3 Set. - $\quad$ Dez. $2013 . \quad$ Disponível em:http://www.feminismos.neim.ufba.br/index.php/revista/article/viewFile/84/82 Acesso em: 16 Dez 2015.

BRITO, F.; SOUZA, J. Expansão urbana nas grandes metrópoles o significado das migrações intrametropolitanas e da mobilidade pendular na reprodução da pobreza. São Paulo. Perspec. v.19 n.4 São Paulo Oct./Dec. 2005. Disponível em: 
Ivete de Aquino Freire, Ramón Núñes Cárdenas, Manifestação de Lazer na História de Vida de Idosas... Rosa de Luz A. Dos Reis Miranda Sá,

Ednes P. Dos Santos Souza e Paola Lima Tristão

http://www.scielo.br/scielo.php?script=sci_arttext\&pid=S0102-88392005000400003

Acesso em: 27 Jul. 2017.

BRUHNS, H.T. Relações entre Educação Física e o lazer. In: (Org.) Heloisa Turini Bruhns. Introdução aos estudos do Lazer. Unicamp: Campinas, 1997

BRUSCHINI, C. O trabalho da mulher brasileira nas décadas recentes. Estudos feministas, $1994 . \quad$ Disponível em: https://periodicos.ufsc.br/index.php/ref/article/viewFile/16102/14646 . Acesso em: 15 mar. 2018.

CAMARGO, L. O. L. O que é lazer. São Paulo: Brasiliense, 1989.

COSTA, L. As arquibancadas da torcedora. A presença feminina nos estádios brasileiros... - Disponível em: https://blogdojuca.uol.com.br/2016/07/as-arquibancadasda-torcedora-a-presenca-feminina-nos-estadios-brasileiros/ . Acesso em: 01 set. 2017.

DEPARTAMENTO DE VIGILÂNCIA, PREVENÇÃO E CONTROLE DAS IST, DO HIV/AIDS E DAS HEPATITES VIRAIS. Ministério da Saúde. 2006. Disponível em: http://www.aids.gov.br/ . Acesso em: 21 dez. 2017.

DUMAZEDIER, J. Lazer e cultura popular. São Paulo: Perspectiva, 1973.

FRANZINI, F. Futebol é "coisa para macho"? Pequeno esboço para uma história das mulheres no país do futebol. Rev. Bras. Hist. v. 25 n. 50 São Paulo July/Dec. 2005. Disponível em: http://www.scielo.br/scielo.php?script=sci_arttext\&pid=S010201882005000200012 . Acesso em: 01 set. 2017.

GOMES, E. O Segundo Ciclo da Borracha e a criação do Território Federal do Guaporé (I Parte). 2013. Disponível em: < http://rondoniaempauta.com.br/nl/historia/osegundo-ciclo-da-borracha-e-a-criacao-do-territorio-federal-do-guapore-i-parte/>

Acesso em: 25 jul. 2017.

GOMES, C.; PINHEIRO, M.; LACERDA, L. Direitos Sociais: Questão de acesso e participação. In: Lazer, turismo e inclusão social: Intervenção com idosos. Belo Horizonte: Editora UFMG, 2010. Disponível em: http://www2.esporte.gov.br/arquivos/snelis/esporteLazer/cedes/lazerTurismoInclusaoSo cial.pdf . Acesso em: 16 ago. 2016.

GOMES, C. L. Verbetes Lazer - concepções. In: GOMES, C.L. (Org.). Dicionário crítico do lazer. Belo Horizonte: Autêntica, 2004.

; PINHEIRO, M.; LACERDA, L. Lazer, turismo e inclusão social: Intervenção com idosos. Belo Horizonte: Editora UFMG, 2010. Disponível em: http://www2.esporte.gov.br/arquivos/snelis/esporteLazer/cedes/lazerTurismoInclusaoSo cial.pdf . Acesso em: 16 ago. 2016.

GORAYEB, A. Território Federal do Guaporé. Coluna do Fundo do Baú. 2015. Disponível

em: 
Ivete de Aquino Freire, Ramón Núñes Cárdenas, Manifestação de Lazer na História de Vida de Idosas... Rosa de Luz A. Dos Reis Miranda Sá,

Ednes P. Dos Santos Souza e Paola Lima Tristão

http://www.newsrondonia.com.br/noticias/territorio+federal+do+guapore/63083

Acesso em: 23 jul. 2017.

LEANDRO, R. V. Os ciclos ficcionais da borracha e a formação de um memorial literário da Amazônia. Universidade de Brasília. Instituto de Letras. Departamento de Teoria Literária e Literaturas. Programa de Pós-graduação em Literatura. Brasília-DF. $2014 . \quad$ Disponível em: http://repositorio.unb.br/bitstream/10482/17742/1/2014_RafaelVoigtLeandro.pdf Acesso em: 21 jul. 2017.

LEVY, M.S.F. A escolha do cônjuge. Rev. bras. estud. popul. vol.26 no.1 São Paulo Jan./June 2009. Disponível em <http://www.scielo.br/pdf/rbepop/v26n1/v26n1a09.pdf>. Acesso em: 01 out. 2017.

MAMBRINI, V. Costumes, ídolos e desafios da mulher de 1930. Revista eletrônica Último Segundo. São Paulo. 2010. Disponível em: < http://ultimosegundo.ig.com.br/revolucao1930/costumes-idolos-e-desafios-da-mulherde-1930/n1237772885629.html> . Acesso em: 28 jul. 2017.

MARCASSA, L. Lazer: Educação. In: (Org.) Christianne Luce GOMES. Dicionário Crítico do lazer. Belo Horizonte: Autêntica, 2004. Disponível em: http://www.cdi.uneb.br/observatorio_arte_movimento/wpcontent/uploads/2015/12/livro-dicion\%C3\%A1rio-cr\%C3\%ADtico-do-lazerchristianne-luce-gomes.pdf . Acesso em: 23 jul. 2017.

MARCELINO. N.C. Atividade e passividade. Suplemento Lazer e Turismo, Correio Popular, Campinas, 1987.

O conceito de lazer nas concepções da Educação Física Escolar: o dito e o não

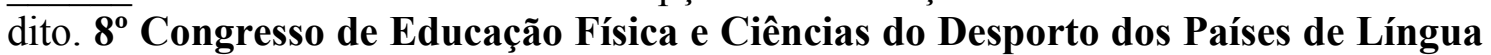
Portuguesa. 1993. Disponível em: https://ufsj.edu.br/portalrepositorio/File/dcefs/Prof._Adalberto_Santos2/13o_conceito_de_lazer_nas_concepcoes_da_ef_escolar-o_dito_e_o_nao_dito10.pdf Acesso em: 20 dez. 2017.

Estudos do lazer: uma introdução. 3 ed. Campinas: autores associados, 2002.

Adulto e lúdico: atuação do profissional de Educação Física no lazer. Motriz, Rio Claro, v.16 n.1 p.103-112, jan./mar. 2010.

MENDONÇA, L.C.P. et al. Pelo direito ao lazer: participação e mobilização social no bairro do Santa Rosa. Campina Grande: EDUEPB, 2009. Disponível em: http://books.scielo.org/id/ggfcb/pdf/lemos-9788578791223-05.pdf . Acesso em: 22 jul. 2017.

MENEGUIN, F.B.; BUGARI, M.S. A informalidade no mercado de trabalho e o impacto das instituições: uma análise sob a ótica da teoria dos jogos. Econ. Apl. v.12 n.3 Ribeirão Preto July/Sept. 2008. Disponível em: 
Ivete de Aquino Freire, Ramón Núñes Cárdenas, Manifestação de Lazer na História de Vida de Idosas... Rosa de Luz A. Dos Reis Miranda Sá,

Ednes P. Dos Santos Souza e Paola Lima Tristão

http://www.scielo.br/scielo.php?script=sci_arttext\&pid=S1413-80502008000300001. Acesso em: 27 jul. 2017.

MORI, G.; SILVA, L.F. Lazer na terceira idade: desenvolvimento humano e qualidade de vida. Motriz, Rio Claro, v.16 n.4 p.950-957, out./dez. 2010. Disponível em: http://www.scielo.br/pdf/motriz/v16n4/a15v16n4.pdf . Acesso em: 01 fev. 2018.

MOSQUERA, J. J. M. Vida adulta: personalidade e desenvolvimento. 3. ed. Porto Alegre: Sulina, 1987.

MOURA, G.A.; SOUZA, L.K. Práticas de Lazer de Idosos Institucionalizados. Rev. Movimento. Porto Alegre, v. 19, n. 04, p. 69-93, out/dez de 2013. Disponível em: http://www.seer.ufrgs.br/Movimento/article/viewFile/36131/27445 . Acesso em: 16 dez. 2015.

OLIVEIRA, P.S. O lúdico na vida cotidiana. (Org.) Heloisa Turini Bruhns. Introdução aos estudos do Lazer. Unicamp: Campinas, 1997.

OLIVEIRA, M.K. Jovens e adultos como sujeitos de conhecimento e aprendizagem. Revista Brasileira de Educação. São Paulo: ANPED - Associação Nacional de Pesquisa e Pós-graduação em Educação, n. 12, 1999, p. 59-73.

PEDROSO, C.A.M.Q.; SILVA, F.F.P. Equipamentos de esporte e lazer na cidade: planejamento dos parques urbanos do Recife, PE, Brasil. EFDeportes.com, Revista Digital • Año $16 \cdot \mathrm{N}^{\circ}$ 158. Buenos Aires, Julio de 2011. Disponível em: http://www.efdeportes.com/efd158/equipamentos-de-esporte-e-lazer-na-cidade.htm Acesso em: 27 jul. 2017.

PERROT, M. Práticas da memória feminina. Revista Brasileira de História, v. 9, n. $18, \quad$ p. $9 \quad-\neg \quad 18, \quad 1989 . \quad$ Disponível em: http://www.scielo.br/scielo.php?script=sci_nlinks\&ref=000198\&pid=S14132478200900020000200021\&lng=en . Acesso em: 20 fev. 2018

PINTO, R.M.F. et al. Condição feminina de mulheres chefes de família em situação de vulnerabilidade social. Serv. Soc. Soc. n.105 São Paulo Jan./Mar. 2011. Disponível em http://www.scielo.br/scielo.php?script=sci_arttext\&pid=S0101-66282011000100010 . Acesso em: 10 out. 2017.

PLONER, K.S. et al. O significado de envelhecer para homens e mulheres. Disponível em http://books.scielo.org/id/hn3q6/pdf/silveira-9788599662885-14.pdf . Acesso em: 10 out. 2017.

PORTAL DA AMAZÔNIA. Borracha: apogeu e decadência. Disponível em http://portalamazonia.com.br/secao/amazoniadeaz/interna.php?id=114 Acesso em: 20 jul. 2017.

POSSAMAI, A.M; GASTAL, S.; NEGRINE, A. A viagem na memória do idoso. Anais da Associação Brasileira de Pesquisa e Pós-graduação, 2009. 
Ivete de Aquino Freire, Ramón Núñes Cárdenas, Manifestação de Lazer na História de Vida de Idosas... Rosa de Luz A. Dos Reis Miranda Sá,

Ednes P. Dos Santos Souza e Paola Lima Tristão

RADICCHI, M.R. et al. Descrição dos espaços esportivos de lazer e educação na cidade de Parintins, Amazonas. Rev. Bras. Ativ. Fis. Saúde. Pelotas/RS. 20(6):626-628. 2015. Disponível

em: https://periodicos.ufpel.edu.br/ojs2/index.php/RBAFS/article/view/5898/5244 . Acesso em: 18 ago. 2016.

SARTORI, J. Memória de idosos. Sem Aspas, Araraquara, v. 2, n. 1, 2, p. 95-107, 2013.

SILVEIRA, R.M.G. Diversidade de gênero: mulheres. Disponível em:http://www.dhnet.org.br/dados/cursos/edh/redh/03/03_rosa1_diversidade_genero.pd f. Acesso em: 16 dez. 2015.

SOUSA, R.G. Movimento Feminista. As Mulheres na História. Mundo educação. Disponível em: http://mundoeducacao.bol.uol.com.br/historiageral/movimento-feminista.htm . Acesso em: 01 set. 2017.

SPINDOLA, G. Trajetória do Poder da Mulher: do lar ao mercado de Trabalho. Curso de especialização em Gestão de equipe. Disponível em: https://pt.slideshare.net/eudelucy/a-trajetria-do-poder-da-mulher-do-lar-ao-mercado-detrabalho . Acesso em: 28 jul. 2017.

SPINDOLA, T.; SANTOS, R.S. Trabalhando com a história de vida: percalços de uma pesquisa(dora?). Rev Esc Enferm USP, 2003. Disponível em: http://www.ee.usp.br/reeusp/upload/pdf/207.pdf . Acesso em: 26 jul. 2017.

VERSIANI, F. R.; SUZIGAN, W. O processo brasileiro de industrialização: uma visão geral. X Congresso Internacional de História Econômica, Louvain, 1990. Disponível em: http://cac-php.unioeste.br/cursos/toledo/historiaeconomica/eeb1-4.pdf . Acesso em: 15 mar. 2018.

\section{Endereço dos Autores:}

Ivete de Aquino Freire

Rua Alecrim, 5595, Cohab Floresta II

Porto Velho - RO - 76.807-534

Endereço Eletrônico: ivete@unir.br

Ramón Núñes Cárdenas

Avenida Guaporé 4218, bairro igarapé

Porto Velho - RO - 76.824-370

Endereço Eletrônico: rnunezcardenas@yahoo.com.br

Rosa de Luz Ambrósio dos Reis Miranda Sá

Rua Dr Gondim, 5988, Bairro Castanheira

Porto Velho - RO - 76.811-406 
Ivete de Aquino Freire, Ramón Núñes Cárdenas, Manifestação de Lazer na História de Vida de Idosas... Rosa de Luz A. Dos Reis Miranda Sá,

Ednes P. Dos Santos Souza e Paola Lima Tristão

Endereço Eletrônico: rosaluz2008@yahoo.com.br

Ednes Pereira Dos Santos Souza

Av. Lauro Sodré, 1376. Bairro Olaria

Porto Velho - RO - 76.803-702

Endereço Eletrônico: neasouza@yahoo.com.br

Paola Lima Tristão

Rua Capari, 5850. Bairro Lagoa

Porto Velho - RO - 76.812-232

Endereço Eletrônico: paolalima309@gmail.com 